\title{
One in six jobs to go
}

\section{London}

THE Natural History Museum in London is to shed one in six science jobs in the next three years, according to the Museum's 1990-95 corporate plan, released last Monday.

The director of the museum, Neil Chalmers, says that he intends the plan to "concentrate our research effort into a series of programmes concerned with environmental, human wealth and human health issues", adding that "by doing this we plan to avoid the weakness that can arise from spreading ourselves too thinly over too many areas - trying to be all things to all people".

Behind these words lies the hard truth that 98 per cent of the museum's government grant is swallowed by salaries, and jobs will have to go if the museum is to remain flexible and pursue its reorganization plans. By 1992-93, the current staff of 780 will have been cut by 100 .

"Some 40 posts have been saved in 1989-90 through natural wastage and

\section{PARTICLE ACCELERATORS}

\section{Heavy ions on tap in Darmstadt}

\section{Munich}

A UNIQUE combination of an accelerator, a synchrotron and a storage ring for heavy ions was inaugurated this week at the Gesellschaft für Schwerionenforschung (Society for Heavy Ion Research or GSI) at Darmstadt. Although many heavy-ion accelerators operate around the world, the GSI apparatus is unique in its ability to store the ions for further study. With this combination, which cost DM275 million (about \$165 million), researchers at GSI hope to create as many as $\mathbf{6 0 0}$ new shortlived isotopes of known elements, says spokesman Günter Siegert.

The new apparatus can accelerate ions as heavy as uranium, to energies as high as $\mathbf{1 . 3}$ gigaelectron-volts ( $\mathrm{GeV}$ ) per nucleon, and by stripping all 92 orbital electrons away from the nucleus can probe the structure of the innermost electron shells.

Researchers will also use the device to study nuclear physics; some experiments may have astrophysical relevance, as the GSI apparatus can collide heavy ions onto a variety of targets at energies typical of stellar interiors. GSI has applied for a further DM17 million from the West German Research Ministry (BMFT) to create a tumour treatment centre at the new facility.

In November last year, the GSI synchrotron accelerated argon nuclei to an energy of $1.7 \mathrm{GeV}$ per nucleon, the highest energy yet achieved. Steven Dickman there will be a further reduction of 50-60 posts by early 1991 , by natural wastage and redeployment where possible, supplemented by voluntary and, regrettably, by compulsory early retirement where necessary", writes Chalmers in the introduction to the plan, which also notes that 50 posts have been axed since 1983-84 "If we do not take this action, the Museum will gradually be eroded in a haphazard fashion. Posts would be lost in an unplanned way over the years, with immense damage to the Museum." Chalmers urges the government to provide an increase of $£ 4.4$ million over the next five years, over and above the levels indicated by the Office of Arts and Libraries (OAL), which reports to the Arts Minister, Richard Luce. This extra money would ensure that the current government grant keeps pace with inflation. The government grant will be $£ 16.9$ million in $1990-91$, rising to $£ 19.8$ million in 1994-95. But this is based on a fixed annual increase of only 4 per cent, and $£ 21.4$ million is a more likely figure for 1994-95.

Researchers fear that if the OAL does not accede to this request, described in the report as "crucial", job losses could be much worse than those threatened. The gloom is deepened by the fact that the OAL will not respond to the corporate plan for some months. Apprehension among researchers is almost tangible: all they can do, they say, is to return to work conscious that one in six will soon receive a tap on the shoulder.

The corporate plan has had the effect of "daubing blood on our doorposts", says museum worker William Lindsay, a member of the National Executive of the Institute of Professionals, Managers and Specialists, one of the three trades unions in the museum.

An earlier draft of the corporate plan shows that it was drawn up as a rearguard action in part of a long battle with OAL, which sees the museum more as a public attraction than a scientific research institution. The draft is much more combative than the final version, promising a marked decline in all aspects of the museum's work if OAL does not increase its aid substantially. It emphasizes the museum's success in its own, independent fundraising: activities that have risen from 17 per cent of the total budget in 1987-88 to 25 per cent in 1989-90, with a target of 30 per cent by $1994-95$.

"Self-reliance at this level places the Museum among world leaders. The Smithsonian Institution's Natural History Museum in Washington, for instance, still receives 75 per cent of its funding from Federal and State sources", the draft says. These achievements are mentioned in the final plan, but the draft document makes no mention of job cuts. Naturally enough, researchers feel that the plan as amended "sells out staff".

More positively, the plan sets out a bold strategy of exhibitions, increased budgets for curation (as distinct from research) and a science policy based on research topics "to develop basic and applied programmes relevant to contemporary needs and issues". Research will now be based around six research groups, concerned respectively with biodiversity, environmental quality, living resources, mineral resources, human health and human origins.

But Chalmers emphasizes that these changes cannot be made with the present staffing levels and tradition of tenure. Chalmers sees flexibility is the key - job losses will provide for 25 short-term 'new blood' fellowships. Although Chalmers admits that aspects of the plan are painful, he hopes that the scientific staff "will realize and accept the challenges and benefits of this new way of working".

Henry Gee

BSE

\section{Britain not alone in its predicament?}

\section{London}

BovINE spongiform encephalopathy (BSE) may be present at low levels in cattle from several European countries and in the United States, according to Keith Meldrum, chief veterinary officer at the UK agriculture ministry. So far, the disease has been thought to be unique to the United Kingdom and the Irish Republic.

Speaking at the Royal Society in London this week, Meldrum said that some of the Irish cases could not be linked to imported British cattle or feed. "It would not surprise me", he said, if other European Communities states had low levels of BSE infection. In the Netherlands and France cattle were fed meal containing sheep tissues in the early 1980 s, so may have come into contact with the agent believed to cause both scrapie in sheep and BSE in cattle.

Meldrum also pointed to an outbreak of transmissible mink encephalopathy (a similar disease) in Wisconsin in the mid1980s, where mink had been fed exclusively on material from cattle and horses. If the outbreak was linked to diet, then this could indicate a sub-clinical infection of BSE in US cattle, Meldrum suggested.

Meldrum's comments came as the Soviet Union introduced a temporary embargo on imports of British beef and dairy products, because of the BSE problem. The UK Ministry of Agriculture, Fisheries and Food, concerned about the loss of export markets, is anxious to make it clear that BSE may not be an exclusively British disease. PeterAldhous 